\section{BMEDJ}

e-ISSN: 2564 - 6664

DOI: 10.33716/bmedi.1015704

${ }^{1}$ Asst. Prof., Adıyaman University Faculty of Health Sciences, Department of Midwifery, Adıyaman, Türkiye.

${ }^{2}$ Assoc. Prof., Adıyaman University Faculty of Health Sciences, Department of Nursing, Adıyaman, Turkey.

Sorumlu Yazar: Tuba Koç Özkan, Asst. Prof., Adıyaman University Faculty of Health Sciences, Department of Midwifery, Adıyaman, Türkiye. E-mail: tubakocozkan@gmail.com Telefon: +90 5309302601 .

Başvuru Tarihi: 27.10.2021 Kabul Tarihi: 25.11.2021 Yayınlanma Tarihi:30.11.2021

Atıf İcin: Tuba Koç Özkan, Türkan Karaca, The effect of 'pediatric tracheostomy care' online course on nursing students' knowledge and attitudes of nursing caregiving roles, 2021;5(3):157-163.

\title{
The effect of 'pediatric tracheostomy care' online course on nursing students' knowledge and attitudes of nursing caregiving roles
}

\author{
Pediatrik trakeostomi bakımı' çevrimiçi kursunun hemşirelik öğrencilerinin \\ bilgi ve bakım verici rollerine ilişkin tutumlarına etkisi
}

\author{
Tuba Koç Özkan¹, (iD) Türkan Karaca²
}

\section{ABSTRACT}

Aim: It is important for nurses to learn sufficient knowledge and skills about tracheostomy care during their undergraduate education. The study was conducted to determine the effect of pediatric tracheostomy care online course on nursing students' knowledge levels and attitudes regarding their role as caregivers. Material and Method: The study was conducted between February and June 2020 at the faculty of health sciences at a state university in Turkey. A total of 76 third-year nursing students registered in the course of Child Health and Diseases Nursing were included in the study. The data were collected with a descriptive features form, a tracheostomy care knowledge test, an attitude scale regarding nurses' caregiver roles. Students were sent online pretest. After pretesting, students were assigned to experimental group $(n=37)$ and control group $(n=39)$ by randomization. The students in the experimental group were given pediatric tracheostomy online course on certain days using the distance education system of the university. After the course, all students in the groups were sent online post-test. The data were analyzed using $t$ test and Chi-square test. Significance was assessed at the level of $p<0.05$ in the study. Result: It was determined that the students in the experimental group had higher scores in sub-dimension 2, sub-dimension 3 and total scores on tracheostomy care knowledge test and caregiver roles compared to the control group. Conclusion: The online course of pediatric tracheostomy care is effective in increasing nursing students' knowledge of tracheostomy care and their attitudes towards caregiver roles.

Keywords: distance education; nursing education; nursing students; tracheostomy

\section{Öz}

Amaç: Hemşirelerin lisans eğitimleri sürecinde trakeostomi bakımı konusunda yeterli bilgi ve beceri öğrenmeleri önemlidir. Araştırma, pediatrik trakeostomi bakımı' çevrimiçi kursunun hemşirelik öğrencilerinin bilgi ve bakım verici rollerine ilişkin tutumlarına etkisini belirlemek amacıyla yapıldı. Gereç ve Yöntem: Araştırma, Türkiye'de bir devletüniversitesinin sağlıkbilimlerifakültesinde ŞubatHaziran 2020 tarihleri arasında yapılmıştır. Araşttrmaya Çocuk Sağlığı ve Hastalıkları Hemşireliği dersini alan toplam 76 hemşirelik üçüncü sınıf öğrencisi dahil edildi. Veriler tanımlayıcı özellikler formu, pediatric trakeostomi bakımı bilgi testi ve hemşirelerin bakım verici rollerine ilişkin tutum ölçeği ile toplandı. Öğrencilere çevrimiçi ön test gönderildi. Ön testten sonra öğrenciler, basit randomizasyon yöntemi ile deney $(n=37)$ ve kontrol grubuna $(n=39)$ ayrıldı. Deney grubundaki öğrencilere üniversitenin uzaktan eğitim sistemi kullanılarak belirli günlerde pediatrik trakeostomi kursu verildi. Kurstan sonra gruplardaki tüm öğrencilere çevrimiçi son test gönderildi. Veriler t testi ve Ki-kare testi kullanılarak analiz edildi. Araştırmada $p<0.05$ istatistiksel olarak anlamlı kabul edildi. Bulgular: Deney grubundaki öğrencilerin trakeostomi bakım bilgi testi ve bakım verici rollerine ilişkin alt boyut 2, alt boyut 3 ve toplam puanları kontrol grubuna göre daha yüksek olduğu belirlendi. Sonuç: Pediatrik trakeostomi bakımı çevrimiçi kursu, hemşirelik öğrencilerinin trakeostomi bakımı bilgisini ve bakım verici rollerine ilişkin tutumlarını artırmada etkilidir.

Anahtar Kelimeler: uzaktan eğitim; hemşirelik eğitimi; hemşirelik öğrencileri; trakeostomi 


\section{INTRODUCTION}

Tracheostomy is defined as the surgical procedure for creating an opening in the $3^{\text {rd }}$ or $4^{\text {th }}$ cartilage ring in the anterior wall of the trachea to provide airway patency, and regarded as the oldest known life-saving method. $(1,2)$ On the other hand, pediatric tracheostomy is a practice used increasingly along with changing indications. $(3,4)$ Today, the most common indications include prolonged intubation, upper airway anomalies, neurological diseases, craniofacial anomalies, and trauma. $(5,6)$

Tracheostomy practice has higher mortality and morbidity in pediatric patients compared to adult patients. $(7,8)$ Although tracheostomy has a vital importance for providing airway patency, especially pediatric patients experience numerous problems associated with tracheostomy (pneumothorax, apnea, wrong placement of the tube, peristomal skin problems, tracheal stenosis, tracheoesophageal fistula and infection, hemorrhage and airway obstruction). (5,911) In order to prevent the problems that may arise, the pediatric care after tracheostomy should include adequate and balanced nutrition, communication, aspiration, cannula cleaning, cuff management, stoma care and dressing. As can be seen, tracheostomy care refers to a complex process that requires skill and knowledge. $(3,12)$ For this reason, families may feel weak and inadequate during these practices performed in children with tracheostomy, especially during the longterm tracheostomy care. It is known that inappropriate and inadequate pediatric tracheostomy care leads to the increased mortality and morbidity associated with tracheostomy. $(13,14)$ At this point, nurses can provide a major support for children with tracheostomy and their families in the proper management and maintenance of tracheostomy care. For this reason, it is of importance for nurses to acquire adequate knowledge and skills during the undergraduate education, especially in relation to pediatric tracheostomy care, to prevent these problems. In order to become a nurse with adequate knowledge and skills about tracheostomy care in the future, nursing students must first receive an effective training program on this subject. A limited number of studies have been found in the literature review on how pediatric tracheostomy care is provided in student education and its effectiveness. (15-17)

Given the increase in the incidence of pediatric patients with tracheostomy especially in intensive care units (20) encountered by nursing students during their working life, it is believed that there is a need for research in this field. Therefore, the present study was conducted to determine the effect of pediatric tracheostomy care training on nursing students' knowledge levels and attitudes regarding their role as caregivers.

\section{MATERIAL and METHODS}

\section{Study Design}

The study was carried out randomized controlled trial, two group design with the purpose of determining the effect of 'pediatric tracheostomy care' course on nursing students' knowledge and attitudes of nursing caregiving roles.

\section{Study Sample}

The study was carried out between February and June 2020 at the faculty of health sciences at a state university in Turkey. Nurse education in the faculty is four years and each academic year consists of two semesters. The study population included 79 third-year nursing students taking the course child health and diseases nursing in the spring term of 2019-2020 academic years. The course of child health and diseases nursing involves theoretical knowledge, hospital and laboratory practicums. The theoretical teaching was conducted by one lecturer having a PhD degree in child health and diseases nursing. The lecturer who gives the course is also the researcher in this study. The purpose of sampling was to access the whole study population. The inclusion criteria were accepted voluntarily participated, being nursing students who took the pediatric nursing course and completed all 'Pediatric Tracheostomy Care' course. Students who are foreign nationals (mother tongue is not Turkish) and who take the child health and diseases nursing course for the second time were not included in the study.

\section{Randomization}

Randomization was done using the student registration number of the students. The students whose numbers ended with an odd number formed the control group, and the students whose numbers ended with an even number formed the experimental group. Three students in the groups were excluded from the study because of various reasons (not meeting inclusion criteria $(n=1)$ : mother tongue is not Turkish; experimental group $(n=2)$ : not completely filled the instruments). Thus, a total of 76 students, including 39 in the control group, 37 in the experimental group (Figure 1).

\section{Data Collection Tools}

Data were collected through the Descriptive Features Form, Tracheostomy Care Knowledge Test and Attitudes of Nursing Caregiving Roles Survey.

Descriptive Features Form: The form, which was developed by the researchers, consisted of questions that aimed to collect information about nursing students' descriptive characteristics like age, gender, education and received education in tracheostomy care previously. 


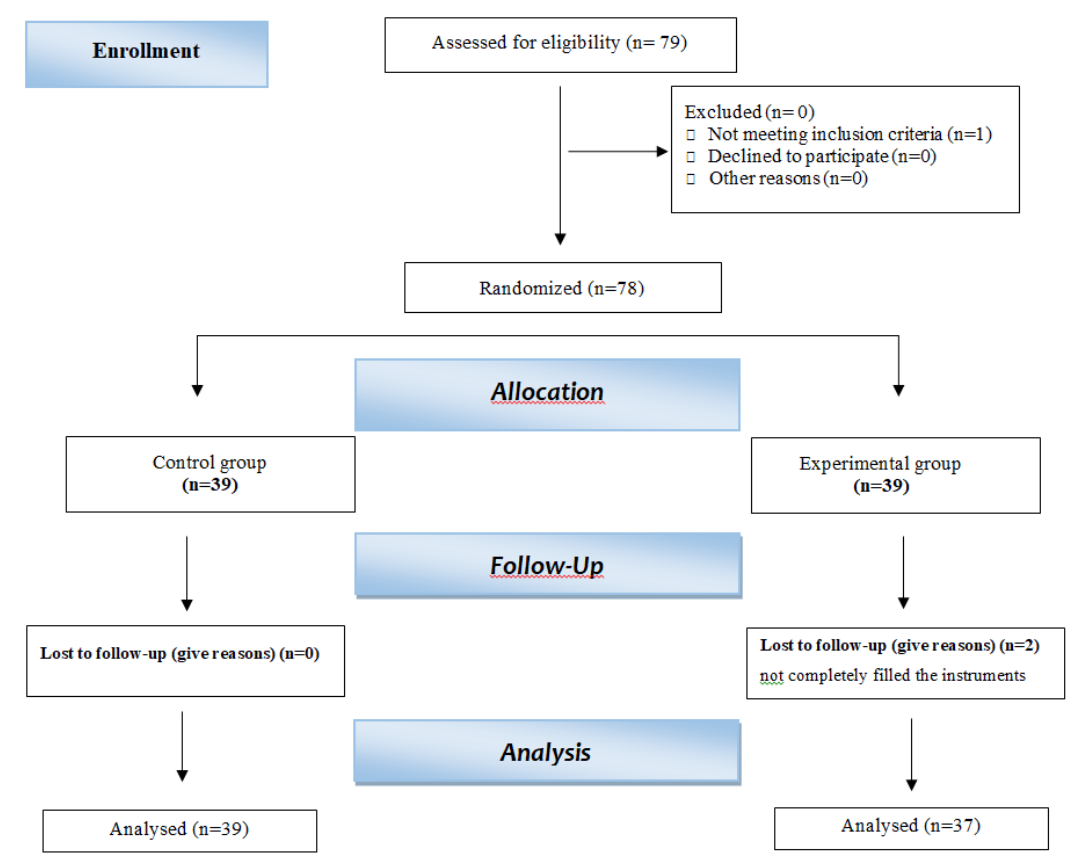

Figure 1. CONSORT flow diagram

Tracheostomy Care Knowledge Test: The test created by the researchers using to the literature. $(9,10,16,18)$ This test was finalized based on the opinions of three specialists in the Fundamentals of Nursing department and Pediatric Nursing. The test comprises 20 five-option multiple choice question. The scores of the test vary between 0 and 100.

Attitude Scale Regarding Nurses' Caregiver Roles (ASNCR): The scale was developed by Koçak et al. (2014) to determine nurses' attitudes towards caregiver roles and its validity and reliability were made by the same researchers. It consists of three subscales (Subscale 1: The attitude towards meeting the patient's self-care needs and the counseling role of the nurse, Subscale 2: The attitude towards the role of the nurse to protect the individual and to respect his rights, Subscale 3: The attitude towards the role of the nurse in the treatment process). The items of the scale are evaluated according to the responses "Strongly disagree", "Disagree", "Partially Agree", "Agree" and "Fully Agree". These evaluations are scored between 1-5 points. The lowest score obtained from the scale is 16 and the highest score is 80 . The scores from the subscale range from 7-35, the scores from the subscale 2 to $4-20$, and the scores from the subscale 3 to $5-25$. Accordingly, as the score obtained from the scale increases, nurses' attitudes towards their caregiver roles are interpreted as positive, and as the score from the scale decreases, it is interpreted as negative. The Cronbach Alpha value for all items of the scale was found to be 0.91. (19) In this study, the Cronbach Alpha value of the scale was calculated as 0.90 .

\section{Data Collection}

Students who meet the sample criteria in the research were sent online pretest questions (Descriptive Features Form, Tracheostomy Care Knowledge Test, ASNCR) and asked to answer. After pretesting, students were assigned to experimental and control groups by randomization.

Three months after the pre-test was administered, the students in the experimental group were given pediatric tracheostomy training on certain days using the distance education system of the university. The training lasted 20 hours in total. Description and history of tracheostomy $(2 \mathrm{hr})$, tracheostomy indications ( $2 \mathrm{hr})$, feeding of tracheostomy child ( $2 \mathrm{hr}$ ), ways to communicate with tracheostomy child $(2 \mathrm{hr})$, aspiration and stoma care ( $4 \mathrm{hr})$, home care of child with tracheostomy (4hr), emergency Applications to be done ( $2 \mathrm{hr}$ ) included topics including nursing diagnoses ( $2 \mathrm{hr}$ ) for tracheostomy. After the training, all students in the groups were sent online post-test questions (Tracheostomy Care Knowledge Test, ASNCR) and asked to answer them.

\section{Data Analysis}

Data were entered and analyzed using SPSS software (Version 17). The data included in the descriptive features form in the study were independent, and the scores on the tracheostomy care knowledge test and the attitude scale of the nurses' caregiver roles were dependent variables. Descriptive characteristics of the students were analyzed using descriptive statistics (percentage, mean, standard deviation). Group differences of descriptive characteristics were analyzed using t test and Chi-square test. Independent sample t test was used to compare tracheostomy care knowledge test and attitude scale scores of students in the experimental and control groups. Significance was assessed at the level of $p<0.05$. 


\section{Ethical Approval}

Prior to the research, permission was obtained from Koçak to use the scale. Ethics committee approval was obtained from the Ethics Committee of a University in order to conduct the research (Desicion Date: 26.11.2019, Desicion Number: 2019/7-7)). Prior to the research, the permissions were obtained from the students by informing about the purpose of the study. The research was carried out in accordance with the Helsinki Declaration 2008 Principles.

\section{RESULTS}

Table 1 shows the descriptive characteristics of the students in the groups. There was no statistically significant difference between the groups in terms of age, gender, education and previous training on tracheostomy care. Students in the groups were found to be similar in terms of their descriptive characteristics (Table 1).

Table 1. The comparison of descriptive characteristics of the students in the groups $(n=76)$

\begin{tabular}{|c|c|c|c|c|c|c|}
\hline \multirow[t]{2}{*}{ Characteristics } & \multirow{2}{*}{\multicolumn{2}{|c|}{$\begin{array}{c}\begin{array}{c}\text { Control Group } \\
\mathrm{n}=39\end{array} \\
\text { mean } \pm S D\end{array}$}} & \multirow{2}{*}{\multicolumn{2}{|c|}{$\begin{array}{c}\begin{array}{c}\text { Experimental Group } \\
\mathrm{n}=37\end{array} \\
\text { mean } \pm S D\end{array}$}} & \multicolumn{2}{|c|}{ Statistics } \\
\hline & & & & & $\mathbf{t}$ & $p$ value \\
\hline \multirow[t]{2}{*}{ Age } & \multicolumn{2}{|c|}{$21.15 \pm 3.63$} & \multicolumn{2}{|c|}{$22.21 \pm 2.65$} & 1.447 & 0.152 \\
\hline & $\mathrm{n}$ & $\%$ & $\mathbf{n}$ & $\%$ & $x^{2}$ & $p$ value \\
\hline \multicolumn{7}{|l|}{ Gender } \\
\hline $\begin{array}{l}\text { Female } \\
\text { Male }\end{array}$ & $\begin{array}{l}27 \\
12 \\
\end{array}$ & $\begin{array}{l}54 \\
46 \\
\end{array}$ & $\begin{array}{l}23 \\
14 \\
\end{array}$ & $\begin{array}{l}46.2 \\
53.8 \\
\end{array}$ & 0.422 & 0.516 \\
\hline \multicolumn{7}{|l|}{ Education } \\
\hline $\begin{array}{l}\text { High School } \\
\text { Science High School }\end{array}$ & $\begin{array}{l}11 \\
28\end{array}$ & $\begin{array}{l}28.2 \\
71.8\end{array}$ & $\begin{array}{l}10 \\
27\end{array}$ & $\begin{array}{l}27.0 \\
73.0\end{array}$ & 0.013 & 0.909 \\
\hline \multicolumn{7}{|c|}{ Receiving Education in Tracheostomy Care Previously } \\
\hline $\begin{array}{l}\text { Yes } \\
\text { No }\end{array}$ & $\begin{array}{l}10 \\
29\end{array}$ & $\begin{array}{l}75.6 \\
74.4\end{array}$ & $\begin{array}{c}8 \\
29\end{array}$ & $\begin{array}{l}21.6 \\
78.4\end{array}$ & 0.170 & 0.680 \\
\hline
\end{tabular}

Table 2 shows the comparison of the total score average of the tracheostomy care knowledge test pretest-posttest total score of the students in the groups. No statistically significant difference was found in the pre-test score averages of the tracheostomy care knowledge test of the students in the experimental and control groups ( $p>.917)$. However, there was a statistically significant difference in the post-test score averages of the tracheostomy care knowledge test of the students in these groups. In the intragroup comparisons, the students in the control group were found to be similar in terms of pre-test, post-test score averages ( $p>$.496), whereas there was a significant difference in the pre-test post-test score averages of the students in the experimental group (Table 2).

Table 2. The comparison of tracheostomy care knowledge test scores in the groups $(n=76)$

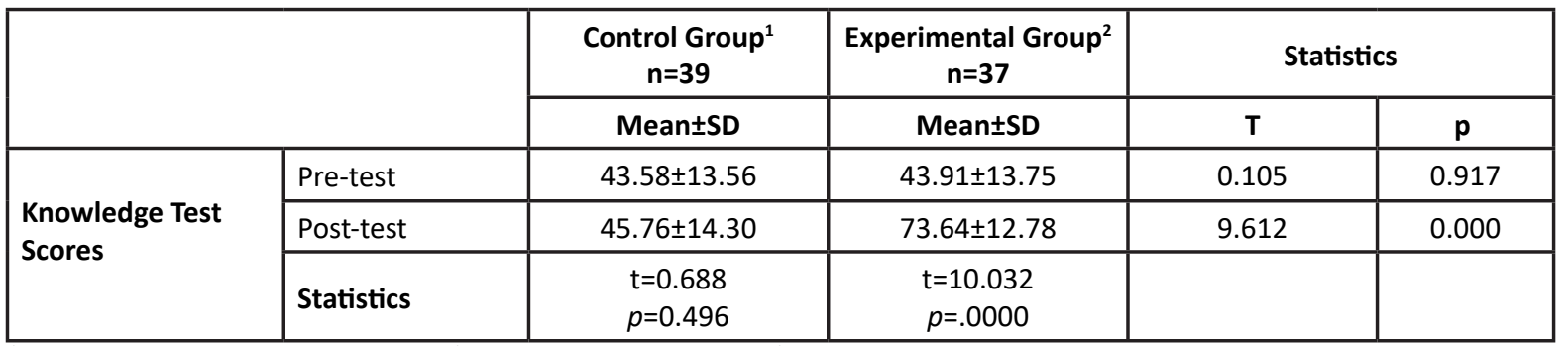

Control Group: The students who took 'Pediatric Tracheostomy Care' course.

${ }^{2}$ Experimental Group: The students who not take 'Pediatric Tracheostomy Care' course $* p<0.05$

Table 3 shows the comparison of the mean scores of the students in the groups from the attitude scale regarding their caregiver roles. Significant differences were found in the sub-scale 2, sub-scale 3 and scale total score averages of the students in the experimental and control groups (Table 3). 
Table 3. The comparison of the nursing students' attitudes of nursing caregiving roles in the groups ( $n=76$ )

\begin{tabular}{|c|c|c|c|c|c|}
\hline \multicolumn{2}{|c|}{ Subscales Scores } & \multirow{2}{*}{$\begin{array}{c}\begin{array}{c}\text { Control Group } \\
n=39\end{array} \\
\text { Mean } \pm \text { SD }\end{array}$} & \multirow{2}{*}{$\begin{array}{c}\begin{array}{c}\text { Experimental Group }^{2} \\
\mathrm{n}=\mathbf{3 7}\end{array} \\
\text { Mean } \pm S D\end{array}$} & \multicolumn{2}{|c|}{ Statistics } \\
\hline & & & & $\mathbf{T}$ & p \\
\hline \multirow{2}{*}{ Subscale 1} & Pre-test & $29.18 \pm 3.30$ & $28.70 \pm 4.02$ & 0.566 & 0.573 \\
\hline & Post-test & $29.72 \pm 4.83$ & $31.03 \pm 3.94$ & 1.290 & 0.201 \\
\hline \multirow{2}{*}{ Subscale 2} & Pre-test & $17.05 \pm 0.58$ & $16.89 \pm 2.35$ & 0.321 & 0.749 \\
\hline & Post-test & $16.87 \pm 2.89$ & $18.46 \pm 2.35$ & 2.616 & $0.011^{*}$ \\
\hline \multirow{2}{*}{ Subscale 3} & Pre-test & $20.10 \pm 2.57$ & $19.54 \pm 2.51$ & 0.963 & 0.339 \\
\hline & Post-test & $20.56 \pm 3.75$ & $22.65 \pm 2.03$ & 2.988 & $0.004 *$ \\
\hline \multirow{2}{*}{ Total Score } & Pre-test & $66.33 \pm 7.21$ & $65.14 \pm 6.61$ & 0.753 & 0.454 \\
\hline & Post-test & $67.15 \pm 10.69$ & $72.14 \pm 7.26$ & 2.363 & $0.021 *$ \\
\hline
\end{tabular}

${ }^{1}$ Control Group: The students who took 'Pediatric Tracheostomy Care' course.

${ }^{2}$ Experimental Group: The students who not take 'Pediatric Tracheostomy Care' course

$* p<.05$

\section{DISCUSSION}

Along with advances in technology, tracheostomy practices continue to increase also in pediatric patients. (20) Most of the studies have focused on the knowledge of tracheostomy care working in the hospitals and their training. (21-25) There are a limited number of studies on the pediatric/adult tracheostomy care training for nursing students. (15-17) Based on these results, the effect of pediatric tracheostomy care training on nursing students' knowledge and attitudes regarding their caregiver roles was investigated.

Pediatric patients with tracheostomy are at high risk for tracheostomy related complications, such as unplanned decanulation, hemorrhage, and tube obstruction. In order to prevent these complications, tracheostomy care should be performed appropriately and effectively. $(7,8,11)$ However, it is reported that the majority of nurses do not receive adequate in-service training and have adequate knowledge on tracheostomy care. $(21,22,26,27)$ This indicates that tracheostomy care, which is vital for performing respiratory function, consists of caregivers who have not been trained on this topic. The study by Pradhan et al. (2018), one of the limited studies evaluating the students' level of knowledge on tracheostomy, reported a need to improve students' knowledge on tracheostomy care. (18) In the study, it was determined that the tracheostomy care pre-test scores of the nursing students in the experimental and control groups were not adequate. In the study, it is believed that the students' ability to answer the questions partially correctly is due to the fact that the topic of tracheostomy care has been discussed in the freshman fundamentals course. This knowledge, however, may be forgotten until starting their working life, and may not be adequate to provide tracheostomy care.

Tracheostomy care is of great importance both in intensive care units and in general services. Primarily, nurses are responsible for the care given to patients with tracheostomy. It is of importance for nurses to be able to provide appropriate tracheostomy care, be aware of the potential complications associated with tracheostomy, and to manage these complications. ${ }^{5}$ This awareness can be raised through training. The limited number of studies conducted with nurses and nursing students shows the positive effects of tracheostomy care training. $(15,16,23-25)$ In their study, Estit et al. (2015) investigated the effect of simulation-based training among professionals on students' knowledge of their roles as health professionals and care of patients with tracheostomy and Passy-Muir valves. In the study, it was reported that the training given to the students increased their levels of knowledge on tracheostomy care. (15) The study by Yelverton et al. (2015) reported that tracheostomy care training provided a significant increase in the number of correct responses given by physicians and nurses to the knowledge test. (23) A study by McDonough et al. (2016) on the standardization of nurse training strategies to improve knowledge and self-efficacy in tracheostomy and laryngectomy care found a significant increase in nurses' knowledge scores after training. (24) The study by Abdelazeen et al. (2019) evaluated the effect of the training program on nurses' knowledge and competence towards endotracheal tube and tracheostomy care of patients with mechanical ventilators. In the study, it was found that training provided a significant increase in the level of knowledge of nurses. (25) In the study, students in the experimental group were found to have a significantly higher post-test score averages compared to both themselves and the control group $(p<.000)$. Qualified tracheostomy care training can be said to have a positive effect on the knowledge level of nursing students.

Care is specific to nursing and it is the most basic and indispensable role of nurses. The evaluation of nurses' attitudes about their role as caregivers provides insight about the nurses fulfillment of patients' self-care needs, their role in the treatment process, and their role as advisors, which addresses the protection of the patients and respecting their rights. (28) There was no study in the literature that investigated the effect of tracheostomy training on the nursing students attitudes regarding their role as caregivers. In a study by Uzelli et al. (2017), the attitudes of nurses in their caregiver roles were evaluated. In the study, it was reported that nurses had a positive attitude towards their caregiver roles. (29) When the pre-test scores of the students in the experimental and control group in the study were evaluated, their attitudes regarding their caregiver roles were found to be positive. In the comparison of pre- and post-test score averages regarding the attitudes about caregiver roles of the students in the experimental group, significant differences were found in the sub-scale 2-3 and 
scale total score averages before and after the training. The increase in students' knowledge about tracheostomy care as a result of the online course on pediatric tracheostomy care may have led to an increase in awareness about the importance of their role as caregivers. Accordingly, the sub-scale 2-3 and the scale total scores can be stated to be affected positively.

\section{Limitations}

The study results cannot be generalized since its sample consists of junior students in a university's nursing department. Another limitation of the study was the lack of blinds due to the online course given by the researcher to the students in the experimental group.

\section{CONCLUSION}

It was found that the pediatric tracheostomy care online course provided to nursing students in the study has increased the students' level of knowledge on pediatric tracheostomy care and improved their attitudes regarding their caregiver roles in nursing.

In order to gain experience, newly graduated nurses in Turkey are often started to work in pediatric/adult intensive care units. Due to the high possibility of encountering with patients with tracheostomy in these units, it is believed that providing the tracheostomy care course to the students is of importance during their education. In this respect, it can be recommended to provide extra-curriculum tracheostomy online course to senior students before the graduation. With the help of further research, training on pediatric tracheostomy care can be given by different course techniques.

Teaching pediatric tracheostomy care during the education process of nursing students may help them approach tracheostomy care more professionally when they start their career and reduce the likelihood of medical errors. The issues that nursing students need support regarding their caregiver roles can be determined the strengths and weaknesses in the attitudes regarding their caregiver roles, and a training opportunity can be provided on related issues.

\section{ACKNOWLEDGEMENT}

The authors thank the students who accepted to participate in the research and Sinan ASLAN who supported the permission stages.

Ethical Declaration: Ethics committee approval was obtained from the Ethics Committee of a University in order to conduct the research (Desicion Date: 26.11.2019, Desicion Number: 2019/7-7)). Prior to the research, the permissions were obtained from the students by informing about the purpose of the study. The research was carried out in accordance with the Helsinki Declaration 2008 Principles.

Conflict of Interest: None.

Financial Support: This research received no specific grant from any funding agency in the public, commercial, or not-forprofit sectors.

Author contributions :

Study design: TK, TKÖ, Data collection: TKÖ, Data analysis: TKÖ, Literature search: TKÖ, TK, Drafting manuscript: TKÖ, TK

\section{REFERENCES}

1. Frost EA. Tracing the tracheostomy. Ann Otol Rhinol Laryngol, 1976;85(1):618-24. doi: https://doi. org/10.1177/000348947608500509

2.Zeitels SM, Broadburst MS, Akst LM, Lopez-Guerra G. The History of Tracheotomy and Intubation. Myers EN, Johnson JT, editors. Tracheotomy: Airway Management, Communication, and Swallowing. 2.nd ed. San Diego: Singular;1998. P.1-23.

3.Dawson D. Essential principles: tracheostomy care in the adult patient. Nurs Crit Care. 2014;19(2):63-72. doi: 10.1111/ nicc.12076

4. Tolunay I, Yıldızdaş RD, Horoz ÖÖ, Sürmelioğlu Ö, Ekinci F., Petmezci E, et al. Evaluation of our patients who underwent tracheostomy in our pediatric intensive care unit. J Pediatr Emerg Intensıve Care Med. 2015;2:60-4.

5. Morris LL, Whitmer A, McIntosh E. Tracheostomy care and complications in the intensive care unit. Crit Care Nurse 2013;33(5):18-30. doi: 10.4187/respcare.05366

6. Myatt R. Nursing care of patients with a temporary tracheostomy. Nurs Stand. 2015;29(26): 42-9. doi: 10.7748/ns.29.26.42. e9742 
7. Ramsey AM, Brennan S, Stricker A, Riek K, Brown D, Gurtowsky R, et al. Emergency airway and ventilator procedures for community based home care staff validation of an educational program. Pediatric Pulmonology 2018;53(3):374-80. doi: 10.1002/ppul.23936

8. Shay S, Shapiro NL, Bhattacharyya N. Revisits after pediatric tracheotomy: airway concerns result in returns. International Journal of Pediatric Otorhinolaryngology 2018;104(2018):5-9. doi: 10.1016/j.ijporl.2017.10.021

9. Colwell JC. Skin Integrity and Wound Care. Potter P, Perry A, editors. Fundamentals of Nursing. 9th ed. USA: Mosby Elsevier Publishing. 2016. P. 1184.

10. Panwar PK, Tiwai N. Medical-Surgical Nursing. 5th ed. India: Aıtbs Publishing. 2012. p.495-504.

11. Watters KF. Tracheostomy in infants and children, Respir. Care 2017;62(6):799-825. doi: 10.4187/respcare.05366

12. Freeman S. Care of adult patients with a temporary tracheostomy. Nurs Stand. 2011;26(2):49-56. doi: 10.7748/ ns2011.09.26.2.49.c8706

13. Can FK, Anıl AB, Anıl M, Gümüşsoy M, Çitlenbik H, Kandoğan T, et al. The outcomes of children with tracheostomy in a tertiary care pediatric intensive care unit in Turkey. Turkish Pediatrics Archive 2018;53(3):177-184.

14. Doğru A, Resul Yılmaz R. Our tracheostomy experiences in pediatric intensive care unit. Pediatric Practice and Research 2019;7(4):604-7.

15. Estis JM, Rudd AB, Pruitt B, Wright T. Inter-professional simulation-based education enhances student knowledge of health professional roles and care of patients with tracheostomies and Passy-Muir ${ }^{\circledR}$ Valves. Journal of Nurse Education Practice 2015;5(6),123-8. doi: 10.5430/jnep.v5n6p123

16. Kanakalmath RC, Patali CS, Pinnapati SS, Ronad SKA. Study to evaluate the effectiveness of planned teaching programme on knowledge regarding tracheostomy care among final year gnm students in selected schools of nursing at Bagalkot, Karnataka. International Journal of Innovative Science and Research Technology 2018;3(11):129-137.

17. Bıyık-Bayram S, Çalışkan N. Effect of a game-based virtual reality phone application on tracheostomy care education for nursing students: A randomized controlled trial. Nurse Education Today 2019;79(2019):25-31. doi: 10.1016/j. nedt.2019.05.010

18. Pradhan A, Neupane N, Sah SK, Kuwar S, Shah S. Knowledge regarding tracheostomy care among nursing students, Int. Journal of Adv. Microbiol. Health. Res. 2018;2(2):23-29.

19. Koçak C, Albayrak SA, Büyükkayacı-Duman N. Developing an attitude scale for nurses' caregiver roles: a validity and reliability study. Journal of Education and Research in Nursing, 2014;11(3):16-21.

20. Ogilvie LN, Kozak JK, Chiu S, Adderley RJ, Kozak FK. Changes in pediatric tracheostomy 1982-2011, a Canadian tertiary children's hospital review. J Pediatr Surg. 2014;49(11):49-1553.

21. Jacob B, Ramesh A. Efficacy of planned teaching on knowledge regarding tracheostomy suctioning among staff nurses. International Journal of Science and Research (IJSR) 2015;4(7):169-75.

22. Dorton LH, Lintzenich CR, Evans AK. Simulation model for tracheotomy education for primary health-care providers. Ann Otol Rhinol Laryngol 2014;123(1):11-18. doi: 10.1177/0003489414521144

23. Yelverton JC, Nguyen JH, Wan W, Kenerson MC, Schuman TA. Effectiveness of a standardized education process for tracheostomy care. The Laryngoscope 2015;125(2):342-7. doi: 10.1002/lary.24821

24. McDonough K, Crimlisk J, Nicholas P, Cabral H, Quinn EK, Jalisi S. Standardizing nurse training strategies to improve knowledge and self-efficacy with tracheostomy and laryngectomy care. Applied Nursing Research 2016;32(2016):212-6. doi: 10.1016/j.apnr.2016.08.003

25. Abdelazeem E, Fashafsheh I, Fadllalah H, 2019. Effect of training program on nurses' knowledge and competence regarding endotracheal tube and tracheostomy care in mechanically ventilated patients. International Journal of Nursing 2019;6(1):48-57. doi: 10.15640/ijn.v6n1a6

26. Agarwal A, Marks N, Wessel V, Willis D, Bai S, Tang X, et al. Improving knowledge, technical skills, and confidence among pediatric health care providers in the management of chronic tracheostomy using a simulation model. Pediatric Pulmonology 2016;51(7):696-704. doi: 10.1002/ppul.23355

27. Gaur R, Mudgal SK. Efficacy of interventional package on knowledge regarding tracheostomy care among staff nurses in tertiary care Hospitals, Udaipur (Rajasthan). International Journal of Nursing Education 2018;10(3):87-90. doi: 10.5958/09749357.2018.00073.9 